\title{
Environmental Impact Assessment of Heavy Metals in Surface Disposed Drilling Waste
}

\author{
Ullattumpoyil Nasir, M. Absi Saeed, S. Marzooq Yousif \\ Southern Area Technical Support Department, Saudi Aramco, Dhahran, KSA \\ Email: nasir.ullattumpoyil@aramco.com
}

How to cite this paper: Nasir, U., Saeed, M. A., \& Yousif, S. M. (2021). Environmental Impact Assessment of Heavy Metals in Surface Disposed Drilling Waste. Journal of Geoscience and Environment Protection, 9, 227-238.

https://doi.org/10.4236/gep.2021.99012

Received: August 19, 2021

Accepted: September 27, 2021

Published: September 30, 2021

Copyright (c) 2021 by author(s) and Scientific Research Publishing Inc. This work is licensed under the Creative Commons Attribution International License (CC BY 4.0).

http://creativecommons.org/licenses/by/4.0/

\begin{abstract}
Saudi Arabia has some of the biggest oil and gas reserves in the world, and has expanded its drilling operations gradually to meet the global demand. Improper handling of contaminated drilling wastes may cause serious negative environmental impacts. The current study investigates the toxicological effects of heavy metals in drilling waste by quantification and developing different contamination indices. Solid and liquid samples from different drilling waste pits were collected and analyzed for heavy metals. The average concentration varies significantly and decreases in the order of $\mathrm{Fe}>\mathrm{Al}>\mathrm{Sr}>\mathrm{Mn}>$ $\mathrm{Cu}>\mathrm{Cr}>\mathrm{Zn}>\mathrm{Ni}>\mathrm{Pb}>\mathrm{Cd}>\mathrm{Ag}>\mathrm{Co}$. The spatial variation showed the highest concentration at SDGM Site 1, West. Comparison of current data showed continental crust average values within the specifications for most of the sites. For metals like $\mathrm{Cd}, \mathrm{Cr}$ and $\mathrm{Cu}$, the concentration is higher than the continental crust value. Indices such as pollution load index, modified degree of contamination etc. were calculated from the available data. The contamination level for different site calculations showed nil to a very low degree of contamination. Spatial variation of the contamination level indicated comparatively higher values for sites UTMN-4 and SDGM-1 North, which indicates the necessity of precautionary methods. The metal concentration in the pit water samples exceeded generally accepted standards, if this water was to be discharged/leaked from the pit. The current study concluded presence of different heavy metals in samples from the drilling waste pits, whereas the degree of contamination is minute.
\end{abstract}

\section{Keywords}

Petroleum, Drilling Waste, Heavy Metals, Toxicity

\section{Introduction}

Oil and gas have many benefits and applications in our world including indus- 
tries, medicine, at home and in transportation. It has shaped our world in many important ways including economic and social development. Petroleum is one of the Earths most in-demand natural resources. Even though it has number of uses, the environmental impact of the petroleum industry is correspondingly extensive and expansive. All activities related to oil \& gas exploration, production, storage and transportation involve waste generation associated to potential risk to the environment. Waste types are related to activities such as drilling operations, production operations, completion operations, Work-over operations, and gas plant operations. During drilling operations, drilling fluid or mud is pumped down the drill string to lift drill cuttings to the surface. The drilling fluid together with the suspended drill cuttings and some heavy metals are carried through the annulus to the surface where the cuttings are separated from the fluid and the fluid is re-injected to lift more cuttings. The solid cuttings are then either treated or disposed of by grinding or injecting them into slurries or keeping them in a waste pit for further treatment and disposal. Different kinds of drilling fluids may be used, including water, bentonite mud, cutting oil, and polymers, which are categorized (according to their main component) as water-based fluids (WBFs), and oil-based fluids (OBFs), or synthetic-based fluids (SBFs). The exact chemical composition of the all varieties of drilling fluids is not known, but studies on their general composition have revealed that they contain complex mixtures of highly volatile materials and toxic substances, such as aromatic compounds and heavy metals.

The production of petroleum involves the generation of drilling waste, which forms a major source of pollution in oil producing environments. Almost every process in the finding and production of petroleum generates many types of wastes which impact the environment negatively such as the generation and disposal of cuttings and excess drilling fluids. These materials are discharged overboard in offshore operations or buried when drilling in land-based locations. Many of the materials and wastes associated with drilling activities have the potential to impact on the environment negatively. The potential impact depends primarily on the material, and its concentration after release of the biotic community that is exposed. Some environmental risks may be significant whiles others are very low. The major impacts of great concerns are pollution of water bodies, pollution of land, as well as air pollution. Improper disposal of contaminated drill cuttings into water bodies (ocean) exposes marine life to danger. There are many studies and research aimed at identifying the best practice for the management and disposal of drilling wastes through a review of the concept of drilling wastes that appear as a result of drilling and exploration for oil wells, and natural gas, and to identify the legislation and standards that are considered when carrying out drilling operations.

The Kingdom of Saudi Arabia is the world's largest producer and exporter of oil, and has one quarter of the world's known oil reserves; including more than 260 billion barrels of crude oil and condensate. Most are located in the Eastern Province, including the largest onshore field in Ghawar. Drilling operations in- 
creased considerably in recent years, and the safe disposal of waste drilling-fluids containing surfactants, hydrocarbons and heavy metals has become one of the core frames of environmental research. Drilling companies utilize different methods for disposal of drilling wastes such as disposal in landfill, slurry injection, salt caverns, onsite evaporation through waste pits, etc. Onsite pits are the most common methodology applied to disposal of drilling wastes, followed by onsite evaporation, which is the most misunderstood or misapplied disposal technique. Depending on the fluid type, duration of storage, soil condition, and pit lining, this disposal method can pose nonrepairable impacts to the environment surroundings including groundwater contamination. One of the major pollutants is the heavy metal, which causes a serious threat to ecosystems. The objective of the current study is to quantify different types of heavy metals in pit fluid and soil in the waste pits of some sites in the Eastern Province of Saudi Arabia. The current study investigates the level of heavy metal contaminants in drilling waste samples in terms of toxicological effects. The study also aims to understand the degree of contamination in terms of different indices and international standard guidelines.

\section{Literature Review}

Ismail et al. (2017) addressed some general environmental concerns related to the management of drilling fluids in terms of various fluids types. The paper also highlighted the negative environmental impacts of the improper disposal practices of drilling wastes. The researcher explained different types of drilling fluids and their characteristics and compositions, and environmental issues associated with drilling fluid. The researcher also mentioned the impacts of this fluid of the imposes on the surrounding environment. Dispersed oil, aromatic hydrocarbons and alkylphenols (AP), heavy metals, and naturally occurring radioactive material (NORM) are of particular environmental concern (Beyer et al., 2020). The study of Gonzalez et al. (2010) showed that new waste treatment and disposal practices are being used in Texas and Louisiana to reduce, reuse and recycle drilling waste. The study by Rojas et al. (2007) reported that the remediation of drilling fluids-polluted sites in the southeast of Mexico is a top priority for the Mexican oil industry. Kinigoma (2001) showed in his studies that the effect of drilling fluid additives on the Soku oil field environment has been examined. Soil and reserve pits in various locations were assessed for some physico-chemical characteristics and heavy metal content using standard methods for water and wastewater analysis.

Toxicity seems to be determined primarily by the hydrocarbon content (Grant \& Briggs, 2002), but mud chemicals and heavy metals from impurities in the barite may add to this. Olsgard and Gray (1995) argued that as hydrocarbons become less of a problem around old cuttings piles, the metals will become the main source of environmental impact. This is yet to be demonstrated. Grant and Briggs (2002) found that metal levels were too low to explain toxicity beyond sites immediately adjacent to a large cuttings pile at the UK "NWHutton" field. Recent studies have also confirmed that metals can be an important issue of en- 
vironmental concern owing to their presence in crude oil (Dekkers \& Daane, 1999). Bakke et al. (2013) stated barite is also used as a weighting agent in drilling muds as it is a primary source of toxic heavy metals in drilling waste discharges. In a statistical analysis the researcher found some correlation between cadmium $(\mathrm{Cd})$ and mercury $(\mathrm{Hg})$ concentrations, and the concentrations of some other trace metals in the barite.

Few studies were also reported in the Arabian Gulf to assess the heavy metal contamination in bottom sediments (El Tokhi et al., 2017). Abu Khamsin (1997) explained in his paper presented at the Middle East Drilling Technology Conference "The Environmental Regulations for Drilling Operations in Saudi Arabia", that there are several environmental regulations that any drilling and work over contractor must follow when working in Saudi Arabia onshore and offshore areas. These regulations are corporate, national, regional and global in nature. These environmental regulations are established to control drilling operations and minimize their impact on the environment.

\section{Materials and Method}

The Ghawar field comprises six main production areas, namely Fazran, Ain Dar, Shedgum, Uthmaniyah, Hawiyah, and Haradh, in the eastern region of the Empty Quarter desert, along the western Gulf coast (Figure 1). The field measures approximately $280 \mathrm{~km}$-long and up to $36 \mathrm{~km}$-wide (Saner et al., 2005). Drilling wastewater including drilling cuttings, and wash water are collected in the disposal pit, evaporated or treated and are complying with the notified standards for onshore disposal. Well-designed pits collect these wastes in different locations of these great oil fields.

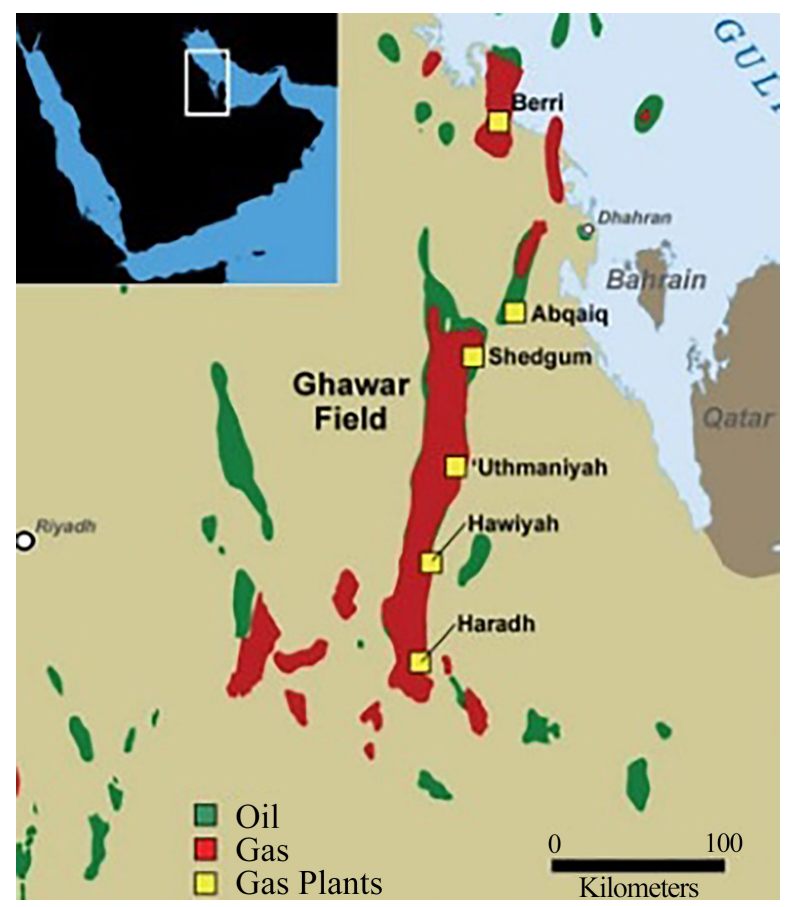

Figure 1. Map of the Ghawar Field comprising major production areas. 
The sampling stations include areas near the Uthmaniyah and Shedgum fields. A total of ten soil samples and two water samples were taken from the locations, Uthmaniyah and Shedgum. The sampling station was selected in different areas and also on different parts of the same pit to know the spatial variation. To ensure the representative sampling, discrete grab samples of waste water and soil were collected in wide-mouthed sterile bottles from various points of the waste pit site. The samples were brought to the laboratory using ice bags and stored in a deep freeze unit until the drying procedure (UNEP, 1985). The soil samples were first dried and thoroughly mixed to achieve homogeneity and sieve using a USS \#10 sieve. One gram (dry weight) of the sample is acid digested using EPA standard method (EPA 3050B, 1988). The digested samples were analyzed for total heavy metals by inductively coupled plasma (ICP) following the standard procedure (ASTM D1976, 2020). The concentration of heavy metal is expressed in $\mathrm{mg} / \mathrm{Kg}$ for the soil samples. The leachate water samples were acidified and analyzed for total heavy metal contents and are reported in $\mathrm{mg} / \mathrm{L}$.

\section{Assessment of Sediment Contamination}

Sediments have the capability to record the history and indicate the degree of pollution. To assess the degree of pollution, it should be compared with an unpolluted reference material (geochemical background). The reference material represents a benchmark to which the metal concentrations in the polluted samples are compared and measured. Many authors have used the average shale values or the average crustal abundance data as reference baselines. In this work average shale values are used for reference material for background values.

\section{Results and Discussions}

There are concerns on environmental levels of heavy metals and their effects on human health (Davies et al., 2005). Concentration of total heavy metals at each sampling locations was tabulated in Table 1 and Table 2 and Figure 2. The data shows a clear enrichment of metals in soils compared to the liquid sample. The average concentration of the heavy metals in the solid samples varies significantly and decreased in the order of $\mathrm{Fe}>\mathrm{Al}>\mathrm{Sr}>\mathrm{Mn}>\mathrm{Cu}>\mathrm{Cr}>\mathrm{Zn}>\mathrm{Ni}>$ $\mathrm{Pb}>\mathrm{Cd}>\mathrm{Ag}>\mathrm{Co}$. The above variation is in the same order reported by Elilyas et al. (2019) for drill cuttings, which indicates that drill cuttings are contributing heavy metals to the waste pits. The average range for individual heavy metals in the solid samples is as follows: $\mathrm{Al}(546-12,234 \mathrm{mg} / \mathrm{kg}), \mathrm{Zn}(6-49 \mathrm{mg} / \mathrm{kg}), \mathrm{Ni}(4$ - $22 \mathrm{mg} / \mathrm{kg}), \mathrm{Pb}(1-29 \mathrm{mg} / \mathrm{kg}), \mathrm{Cr}(6-55 \mathrm{mg} / \mathrm{kg}), \mathrm{Cu}(1-87 \mathrm{mg} / \mathrm{kg}), \mathrm{Cd}(1-11$ $\mathrm{mg} / \mathrm{kg}), \mathrm{Ag}(0.5-1.5 \mathrm{mg} / \mathrm{kg}), \mathrm{Sr}(39-870 \mathrm{mg} / \mathrm{kg}) \mathrm{Fe}(2096-10,232 \mathrm{mg} / \mathrm{kg}) \mathrm{Mn}$ (39- $348 \mathrm{mg} / \mathrm{kg})$ and Co (0 - $2 \mathrm{mg} / \mathrm{kg})$.

An attempt was made to compare these heavy metal concentrations with average continental crust value. The data indicates that heavy metals such as $\mathrm{Cd}$, $\mathrm{Cr}, \mathrm{Cu}, \mathrm{Pb}$ and $\mathrm{Ni}$ exceed the average crust value in some locations. The range of contaminant concentrations and the physical and chemical forms will also depend on activities and disposal patterns for the contaminated waste on the site. 
Drilling operation is thus, one of the major ways human activities can contribute to environmental pollution through surface exposure to these naturally

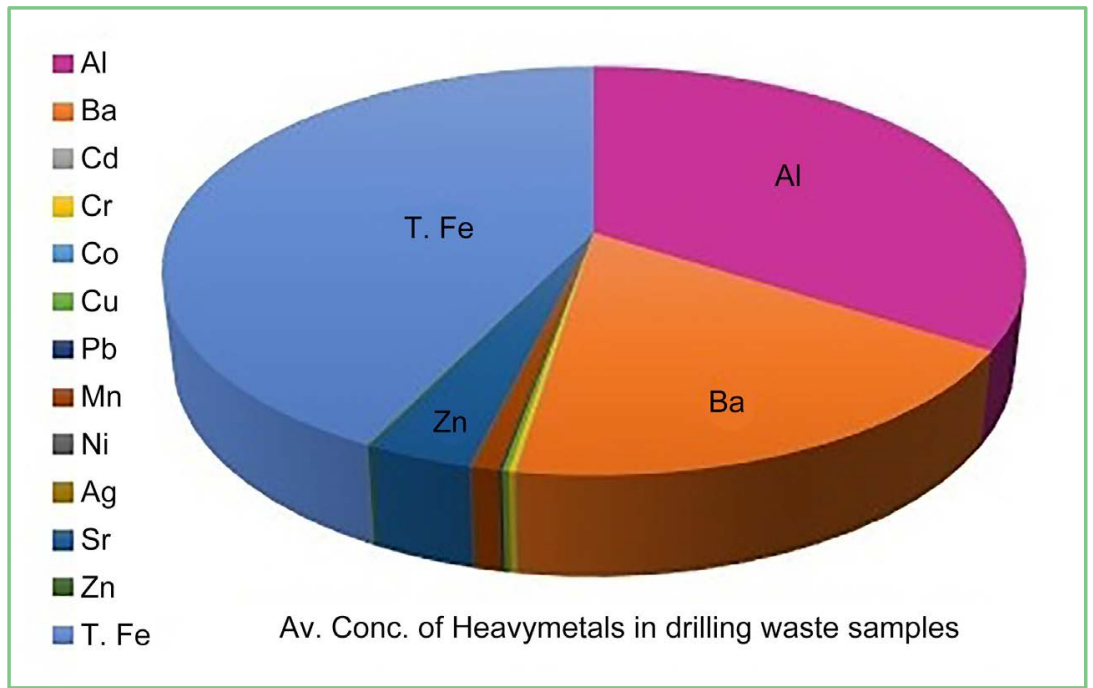

Figure 2. Pie chart for average concentration of heavy different heavy metals in drilling waste.

Table 1. Heavy metal concentration $\left(\mathrm{mg} \cdot \mathrm{kg}^{-1}\right)$ in soil and water from drilling waste pits.

\begin{tabular}{|c|c|c|c|c|c|c|c|c|c|}
\hline Site No. & Area & Sample Type & $\mathrm{Al}$ & $\mathrm{Ba}$ & $\mathrm{Cd}$ & $\mathrm{Ca}$ & $\mathrm{Cr}$ & Co & $\mathrm{Cu}$ \\
\hline 1 & UTMN & Solid & $12,234.50$ & 257.85 & $<0.01$ & 157,000 & 28.39 & $<0.01$ & 14.76 \\
\hline 2 & UTMN & Solid & 590.40 & 12.80 & $<0.01$ & 38,800 & 13.27 & $<0.01$ & 7.91 \\
\hline 3 & UTMN & Solid & 546.25 & 1533.25 & $<0.01$ & 144,000 & 18.18 & $<0.01$ & 24.38 \\
\hline 4 & UTMN & Solid & 1984.00 & 49.49 & 1.4 & 31,100 & 10.72 & 1.83 & 0.7 \\
\hline 5 & UTMN & Solid & 4815.75 & 2471.85 & $<0.01$ & 52,400 & 28.01 & 0.58 & 87.18 \\
\hline 1. North & SDGM & Solid & 5928.40 & 886.80 & $<0.01$ & 71,000 & 55.33 & $<0.01$ & 77.54 \\
\hline 1. South & SDGM & Solid & 4844.00 & 179.70 & $<0.01$ & 122,000 & 32.14 & $<0.01$ & 7.72 \\
\hline 1. East & SDGM & Solid & 6788.00 & 14.20 & $<0.01$ & 82,100 & 25.79 & $<0.01$ & 8.63 \\
\hline 1. West & SDGM & Solid & 4066.70 & 463.10 & 11.35 & 67,400 & 47.29 & $<0.01$ & 33.99 \\
\hline 2 & SDGM & Solid & 1448.00 & 1875.00 & $<0.01$ & 38,800 & 6.35 & $<0.01$ & 1.91 \\
\hline 3 & SDGM & Solid & 2382.00 & $18,445.00$ & $<0.01$ & 93,600 & 8.45 & 0.11 & 11.58 \\
\hline 4 & SDGM & Solid & 2695.00 & 37.20 & $<0.01$ & 51,600 & 6.71 & 0.07 & 6.11 \\
\hline 5 & SDGM & Solid & 1809.00 & 693.00 & $<0.01$ & 110,000 & 12.28 & $<0.01$ & 12.32 \\
\hline \multicolumn{3}{|c|}{ Average solid, mg/kg } & 3856.3 & 2070.7 & 6.4 & $81,523.1$ & 22.5 & 0.2 & 22.7 \\
\hline \multicolumn{4}{|c|}{ Continental crust average, $\mathrm{mg} / \mathrm{kg}$} & & 0.10 & & 35.00 & 10.00 & 25.00 \\
\hline 5 & SDGM & Liquid & 0.29 & 1.10 & $<0.01$ & 479 & $<0.01$ & 0.02 & $<0.01$ \\
\hline 5 & UTMN & Liquid & 0.45 & 2.06 & 0.13 & 1210 & 0.09 & ---- & 0.13 \\
\hline \multicolumn{3}{|c|}{ Average liquid, $\mathrm{mg} / \mathrm{L}$} & 0.37 & 1.58 & 0.13 & 844.5 & 0.09 & 0.02 & 0.13 \\
\hline
\end{tabular}


Table 2. Heavy metal concentration $\left(\mathrm{mg} \cdot \mathrm{kg}^{-1}\right)$ in soil and water from drilling waste pits.

\begin{tabular}{|c|c|c|c|c|c|c|c|c|c|}
\hline Site No. & Area & Sample Type & $\mathrm{Pb}$ & $\mathrm{Mn}$ & $\mathrm{Ni}$ & $\mathrm{Ag}$ & $\mathrm{Sr}$ & $\mathrm{Zn}$ & Fe Total \\
\hline 1 & UTMN & Solid & 5.33 & 103.55 & 14.14 & $<0.01$ & 510 & 13.04 & 7796.35 \\
\hline 2 & UTMN & Solid & 3.63 & 49.15 & 9.45 & $<0.01$ & 270 & 7.98 & 2252.35 \\
\hline 3 & UTMN & Solid & 18.08 & 94.95 & 9.18 & $<0.01$ & 420 & 15.94 & 3030.20 \\
\hline 4 & UTMN & Solid & 9.26 & 49.79 & 6.28 & 0.56 & 39 & 5.7 & 2379 \\
\hline 5 & UTMN & Solid & 28.94 & 136.00 & 12.89 & $<0.01$ & 410 & 25.90 & 5981.45 \\
\hline 1 North & SDGM & Solid & 5.98 & 99.52 & 21.52 & $<0.01$ & 700 & 23.50 & 6959.35 \\
\hline 1 South & SDGM & Solid & 3.38 & 88.21 & 12.60 & $<0.01$ & 530 & 14.67 & 4859.95 \\
\hline 1 East & SDGM & Solid & 1.93 & 68.62 & 11.64 & $<0.01$ & 230 & 12.01 & 4293.10 \\
\hline 1 West & SDGM & Solid & 3.30 & 88.35 & 16.90 & $<0.01$ & 650 & 14.20 & 6884.25 \\
\hline 2 & SDGM & Solid & 6.68 & 39.40 & 4.08 & 0.46 & 95 & 7.53 & 2096 \\
\hline 3 & SDGM & Solid & 11.99 & 54.94 & 6.09 & $<0.01$ & 60 & 10.41 & 2885 \\
\hline 4 & SDGM & Solid & 1.24 & 57.25 & 6.40 & $<0.01$ & 63 & 6.12 & 3168 \\
\hline 5 & SDGM & Solid & 14.19 & 348.00 & 5.78 & 1.32 & 870 & 49.09 & 10,232 \\
\hline \multicolumn{3}{|c|}{ Average solid, mg/kg } & 8.8 & 98.3 & 10.5 & 0.8 & 372.8 & 15.9 & 4832.1 \\
\hline \multicolumn{3}{|c|}{ Continental crust average } & 20.00 & 600.00 & 20.00 & & & 71.00 & 35,000 \\
\hline 5 & SDGM & Liquid & $<0.010$ & 1.98 & $<0.01$ & $<0.01$ & 13 & 1.7 & 9.2 \\
\hline 5 & UTMN & Liquid & 0.14 & 0.03 & 0.13 & 0.17 & 100 & $<0.01$ & ----- \\
\hline \multicolumn{3}{|c|}{ Average liquid, mg/L } & 0.14 & 1.005 & 0.13 & 0.17 & 56.5 & 1.7 & 9.2 \\
\hline
\end{tabular}

occurring subsurface heavy metals of significant concentration. Heavy metal distribution showed a spatial variation with high concentration at SDGM Site 1, West. For water samples, high concentration was recorded for $\mathrm{Cd}$ and $\mathrm{Sr}$, which may be due to differences in the leachability of different heavy metals. For metals like $\mathrm{Cd}, \mathrm{Cr}$ and $\mathrm{Cu}$, the concentrations were higher than the continental crust value. Similar trends were observed for the same site at northern location. The results indicate comparatively higher concentrations of metals at site 1. SDGM.

The highest value of chromium (Cr) obtained in this study is $55.4 \mathrm{mg} / \mathrm{kg}$, which is lower than the maximum allowable standard of $85 \mathrm{mg} / \mathrm{kg}$. So, the study recommends to take initiative measure to control this for any health risk which may cause to both the drilling crew and the people in the environment. The US Environmental Protection Agency (EPA) placed the maximum allowable limit of lead $(\mathrm{Pb})$ in soil to be in the range of $180-200 \mathrm{mg} / \mathrm{kg}$; but the highest concentration reported for the current study is only $28.4 \mathrm{mg} / \mathrm{kg}$, which is in the safe side. The highest heavy metal value for Copper $(\mathrm{Cu})$ for the current study is 87 $\mathrm{mg} / \mathrm{kg}$, which is greater than the DPR target values of $0.30 \mathrm{mg} / \mathrm{kg}$ set for Nigeria standard soil by Department of Petroleum Resources (DPR) (Okoro et al., 2020). $\mathrm{Cu}$ is essential but the high dose can cause anemia and intestinal irritation to the people in direct contact with these cuttings from the lithofacies. Nickel $(\mathrm{Ni})$ on the other hand is essential in small doses, but it can be dangerous when the 
maximum tolerable amounts are exceeded. The current study showed within acceptable ranges for nickel. Lead $(\mathrm{Pb})$ is a toxic metal often studied in literature, and it has a wide range of biological effects depending on the level and duration of the exposure. Our current results indicated within maximum allowable limit for lead according to USEPA, which is safer and won't pose any health concerns.

Groundwater contamination is probably less of a concern in a desert area than in many areas of the world where infiltrating precipitation is likely to leach contaminants from the waste into groundwater that is near the waste pits. It is evident from the data that water in the pits sampled for the study contain metal contaminants at levels that exceeded generally accepted drinking water, human health, and/or agricultural groundwater standards. In addition, if this leachate were to reach surface waters, where aquatic organisms could be exposed to the contaminants. Current study indicated that the metal concentration in the water samples exceeded generally accepted standards, if this water were to be discharged/leaked from the pit. Appropriate measures should be taken to control the future deposition and environmental degradation. The study emphasizes to utilize advanced technologies to minimize or reuse of wastes, which are key strategies in waste avoidance and a sound waste management plan. Two general approaches to waste minimization such as total fluid management (TFM) and environmental impact reduction (EIR) are commonly developed.

\subsection{Evaluation by Contamination Factor (CF)}

The level of metal contamination can be expressed by the contamination factor (CF). $\mathrm{CF}$ is the ratio between the metal content in the sediment to the background value of the metal (Turekian \& Wedepohl, 1961).

$$
\mathrm{CF}=\frac{\mathrm{C} \text { heavy metal }}{\mathrm{C} \text { background }}
$$

According to Hakanson (1980) $\mathrm{CF}<1$ indicates low contamination; $1<\mathrm{CF}<$ 3 is moderate contamination; $3<\mathrm{CF}<6$ is considerable contamination; and $\mathrm{CF}>6$ is very high contamination. Current study indicates that the contamination factor calculated for all the heavy metals were below one, which indicates safe level of heavy metals in these sites.

\subsection{Evaluation by Pollution Load Index (PLI)}

The Pollution Load Index (PLI) represents the number of times by which the heavy metal concentrations in the sediment exceeded the background concentration, and give a summative indication of the overall level of heavy metal toxicity in a particular sample and is determined as the $n^{\text {th }}$ root of the product of $n \mathrm{CF}$.

$$
\mathrm{PLI}=\left(\mathrm{CF}_{1} \times \mathrm{CF}_{2} \times \mathrm{CF}_{3} \times \cdots \times \mathrm{CF}_{n}\right)^{1 / n}
$$

where $\mathrm{CF}_{n}$ is the $\mathrm{CF}$ value of metal $n$. It gives simple and comparative means for assessing the heavy metal pollution level in the sediment sample. The PLI values are interpreted into two levels as polluted (PLI $>1$ ) and unpolluted (PLI $<1$ ) 
(Harikumar et al., 2009). The sites SDGM 1 North and SDGM 3 showed comparatively higher value for PLI. But all the sites recorded the value $<1.0$, which further confirmed unpolluted sites.

\subsection{Comparison Using Modified Degree of Contamination ( $\mathrm{mC}_{\mathrm{d}}$ )}

The modified degree of contamination was introduced to estimate the overall degree of contamination at a given site according to the formula (Abrahim \& Parker, 2008)

$$
\mathrm{mC}_{\mathrm{d}}=\frac{\sum_{i=1}^{i=n} \mathrm{CF}}{n}
$$

where $n$-number of analyzed elements and $i=i^{\text {th }}$ element (or pollutant) and CF-contamination factor. The modified formula is generalized by defining the degree of contamination $\left(\mathrm{mC}_{\mathrm{d}}\right)$ as the sum of all the $\mathrm{CF}$ for a given set of sediment pollutants divided by the number of analyzed pollutants. Using this generalized formula to calculate the $\mathrm{mC}_{\mathrm{d}}$ allows the incorporation of as many metals as the study may analyses with no upper limit. The expanded range of possible pollutants can thus include both heavy metals and organic pollutants should later be available for the studied samples. Level of contamination is expressed as $\mathrm{mC}_{\mathrm{d}}<1.5$ nil to a very low; $1.5 \leq \mathrm{mC}_{\mathrm{d}}<2$ low; $2 \leq \mathrm{mC}_{\mathrm{d}}<4$ moderate; $4 \leq \mathrm{mC}_{\mathrm{d}}<$ 8 high; $8 \leq \mathrm{mC}_{\mathrm{d}}<16$ very high; $16 \leq \mathrm{mC}_{\mathrm{d}}<32$ extremely high; $\mathrm{mC}_{\mathrm{d}} \geq 32$ ultra-high degree of contamination.

For the current study, modified degree of contamination also gave values which are $<1.5$, which again confirms safe concentration level of heavy metals in the waste pit samples. Comparatively high values are obtained for sites UTMN-4 and SDGM-1 North, which gave an indication for taking more measures to control future contamination. So proper remedial measures should be adopted to protect those sites from enrichment and pollution in future. Table 3 shows the spatial variation of contamination factor, PLI and mCd. Figure 3 shows the spatial variation of PLI and $\mathrm{mCd}$ for different sites.

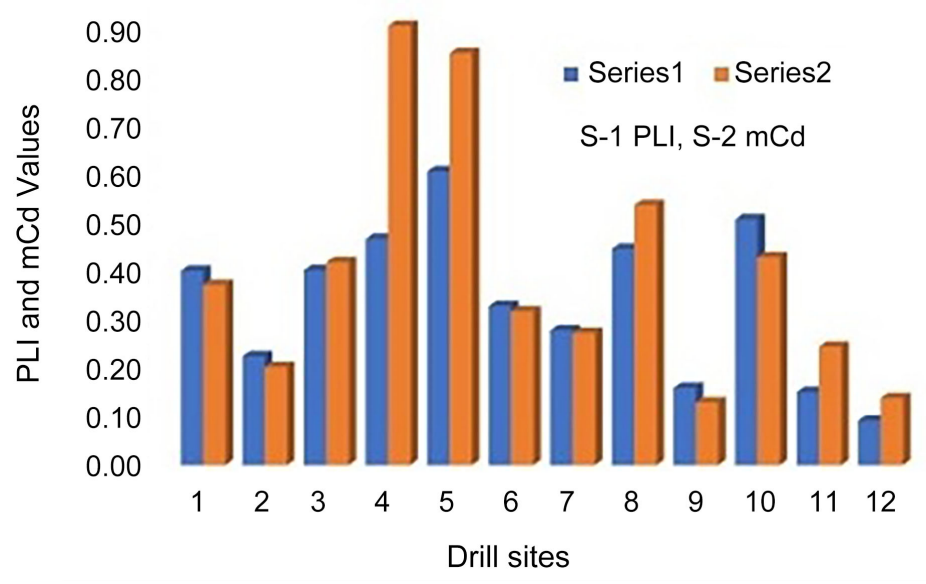

Figure 3. Spatial variation of PLI and $\mathrm{mC}_{d}$ at Eastern Province, Saudi Arabia. 
Table 3. Spatial variation of contamination factor, PLI and $m C_{d}$.

\begin{tabular}{|c|c|c|c|c|c|c|c|c|c|c|c|c|}
\hline \multirow{2}{*}{ Area } & \multirow{2}{*}{ Site } & \multirow{2}{*}{$\begin{array}{l}\text { Sample } \\
\text { type }\end{array}$} & $\mathrm{Cr}$ & Co & $\mathrm{Cu}$ & Fe Total & $\mathrm{Pb}$ & $\mathrm{Mn}$ & $\mathrm{Ni}$ & $\mathrm{Zn}$ & \multirow{2}{*}{ PLI } & \multirow{2}{*}{$\mathrm{mC}_{\mathrm{d}}$} \\
\hline & & & \multicolumn{8}{|c|}{ Contamination Factor (CF) } & & \\
\hline UTMN & 1 & Solid & 0.81 & - & 0.59 & 0.22 & 0.27 & 0.17 & 0.71 & 0.18 & 0.40 & 0.49 \\
\hline UTMN & 2 & Solid & 0.38 & - & 0.32 & 0.06 & 0.18 & 0.08 & 0.47 & 0.11 & 0.22 & 0.33 \\
\hline UTMN & 3 & Solid & 0.52 & - & 0.98 & 0.09 & 0.90 & 0.16 & 0.46 & 0.22 & 0.40 & 0.54 \\
\hline UTMN & 4 & Solid & 0.80 & 0.06 & 3.49 & 0.17 & 1.45 & 0.23 & 0.64 & 0.36 & 0.46 & 0.90 \\
\hline SDGM & 1 North & Solid & 1.58 & - & 3.10 & 0.20 & 0.30 & 0.17 & 1.08 & 0.33 & 0.60 & 0.97 \\
\hline SDGM & 1 South & Solid & 0.92 & - & 0.31 & 0.14 & 0.17 & 0.15 & 0.63 & 0.21 & 0.33 & 0.44 \\
\hline SDGM & 1 East & Solid & 0.74 & - & 0.35 & 0.12 & 0.10 & 0.11 & 0.58 & 0.17 & 0.28 & 0.40 \\
\hline SDGM & 1 West & Solid & 1.35 & - & 1.36 & 0.20 & 0.17 & 0.15 & 0.85 & 0.20 & 0.44 & 0.66 \\
\hline SDGM & 2 & Solid & 0.18 & - & 0.08 & 0.06 & 0.33 & 0.07 & 0.20 & 0.11 & 0.16 & 0.25 \\
\hline SDGM & 3 & Solid & 0.35 & - & 0.49 & 0.29 & 0.71 & 0.58 & 0.29 & 0.69 & 0.50 & 0.55 \\
\hline SDGM & 4 & Solid & 0.24 & 0.01 & 0.46 & 0.08 & 0.60 & 0.09 & 0.30 & 0.15 & 0.15 & 0.24 \\
\hline SDGM & 5 & Solid & 0.19 & 0.01 & 0.24 & 0.09 & 0.06 & 0.10 & 0.32 & 0.09 & 0.09 & 0.14 \\
\hline
\end{tabular}

\section{Conclusion}

The work "Oil Exploration and Production, Environmental Impact Assessment of Heavy Metals in Surface Disposed Drilling Waste" quantifies the heavy metals in present in drilling waste samples collected from one of the major onshore fields. The present study was performed through investigation, field sampling, laboratory experiment and mathematical analysis of the generated data.

1) The study concludes that the drilling activities contribute heavy metals to surrounding ecosystems, but the level is toxicity too low.

2) The average concentration of the heavy metals found in the solid samples varied significantly and decreased in the order of $\mathrm{Fe}>\mathrm{Al}>\mathrm{Sr}>\mathrm{Mn}>\mathrm{Cu}>\mathrm{Cr}>$ $\mathrm{Zn}>\mathrm{Ni}>\mathrm{Pb}>\mathrm{Cd}>\mathrm{Ag}>\mathrm{Co}$.

3) The attempt to compare these heavy metal concentrations with average continental crust value indicated that metals such as $\mathrm{Cd}, \mathrm{Cr}, \mathrm{Cu}, \mathrm{Pb}$ and $\mathrm{Ni}$ exceed the average crust value in some locations, but within maximum allowable limit for lead according to USEPA.

4) Spatial variation indicated comparatively higher concentration of heavy metals at SDGM Site 1, West. Spatial variation of the contamination level indicated ccomparatively higher values for sites UTMN-4 and SDGM-1 North.

5) Waste water samples from the pits were reported to have concentrations, metal contaminants at levels that exceeded generally accepted drinking water, human health, and/or agricultural groundwater standards which are currently not used for above purposes.

6) Toxicity calculated based on different indices indicated nil to low level of pollution in all the selected sites.

7) The study emphasizes to utilize advanced technologies to minimize or 
reuse of wastes, which are key strategies in waste avoidance and a sound waste management plan. Two general approaches to waste minimization such as total fluid management (TFM) and environmental impact reduction (EIR) are commonly developed.

\section{Acknowledgements}

The authors wish to express their gratitude to Saudi Aramco management for allowing us to complete and publish the research work.

\section{Conflicts of Interest}

The authors declare no conflicts of interest regarding the publication of this paper.

\section{References}

Abrahim, G. M. S., \& Parker, R. J. (2008). Assessment of Heavy Metal Enrichment Factors and the Degree of Contamination in Marine Sediments from Tamaki Estuary, Auckland, New Zealand. Environmental Monitoring and Assessment, 136, 227-238. https://doi.org/10.1007/s10661-007-9678-2

Abu Khamsin, S. A. (1997). Environmental Regulations for Drilling Operations in Saudi Arabia. SPE/IADC Middle East Drilling Technology Conference, Bahrain, November 1997, SPE-39256-MS. https://doi.org/10.2118/39256-MS

ASTM D1976 (2020). Standard Test Method for Elements in Water by Inductively-Coupled Plasma Atomic Emission Spectroscopy.

Bakke, T., Klungsøyr, J., \& Sanni, S. (2013). Environmental Impacts of Produced Water and Drilling Waste Discharges from the Norwegian Offshore Petroleum Industry. Marine Environmental Research, 92, 154-169. https://doi.org/10.1016/j.marenvres.2013.09.012

Beyer, J., Goksøyr, A., Hjermann, D. Ø., \& Klungsøyr, J. (2020). Environmental Effects of Offshore Produced Water Discharges: A Review Focused on the Norwegian Continental Shelf. Marine Environmental Research, 162, 2-20. https://doi.org/10.1016/j.marenvres.2020.105155

Davies, B. E., Bowman, C., Davies, T. C., \& Selinus, O. (2005). Chapter 1. Medical Geology: Perspectives and Prospects. In Essentials of Medical Geology (pp. 1-13). Elsevier Inc. https://doi.org/10.1007/978-94-007-4375-5_1

Dekkers, C., \& Daane, R. (1999). Metal Contents in Crudes Much Lower than Expected. Oil Gas Journal, 97, 44-57.

El Tokhi, M., Amin, B. M., \& Alaabed, S. A. (2017). Environmental Assessment of Heavy Metals Contamination of Bottom Sediments of Oman Gulf, United Arab Emirates. Journal of Pollution Effects \& Control, 5, 1-8.

Elilyas, A., Özkan, A., \& Özkan, V. (2009). Heavy Metals Concentrations in Drilling Fluids and Drill Cuttings in Oil Exploration Field in Adiyaman, Turkey.

https://www.researchgate.net/publication/338230343

EPA 3050B (1988). Acid Digestion of Sediments, Sludges, and Soils. EPA Contract No. 68-03-3254.

Gonzalez, M., Wayne, C., \& Dennis, P. (2008). New Reduce, Reuse, Recycle Drilling Waste Treatment Technologies and Programs. The AADE Fluids Conference and EX- 
hibition, Houston, 8-9 April 2008, 1-9.

Grant, A., \& Briggs, A. D. (2002). Toxicity of Sediments from around a North Sea Oil Platform: Are Metals or Hydrocarbons Responsible for Ecological Impacts. Marine Environmental Research, 53, 95-116. https://doi.org/10.1016/S0141-1136(01)00114-3

Hakanson, L. (1980). An Ecological Risk Index for Aquatic Pollution Control: A Sedimentological Approach. Water Research, 14, 975-1001. https://doi.org/10.1016/0043-1354(80)90143-8

Harikumar, P. S, Nasir, U. P., \& Mujeebu Rahman, M. P. (2009). Distribution of Heavy Metals in the Core Sediments of a Tropical Wetland System. International Journal of Environmental Science and Technology, 6, 225-232. https://doi.org/10.1007/BF03327626

Ismail, A. R., Alias, A. H., Sulaiman, W. R. W., Jaafar, M. Z., \& Ismail, I. (2017). Drilling Fluid Waste Management in Drilling for Oil and Gas Wells. Chemical Engineering Transactions, 56, 1351-1356.

Kinigoma, B. S. (2001). Effect of Drilling Fluid Additives on the Niger Delta Environment. A Case Study of the Soku Oil Fields. Journal of Applied Sciences and Environmental Management, 5, 57-61. https://doi.org/10.4314/jasem.v5i1.54943

Okoro, E. E., Okolie, A. G., \& Sanni, S. E. (2020). Toxicology of Heavy Metals to Subsurface Lithofacies and Drillers during Drilling of Hydrocarbon Wells. Scientific Reports, 10, Article No. 6152. https://doi.org/10.1038/s41598-020-63107-3

Olsgard, F., \& Gray, J. S. (1995). A Comprehensive Analysis of Effects of Offshore Oil and Gas Exploration and Production on the Benthic Communities of the Norwegian Continental Shelf. Marine Ecology Progress Series, 122, 277-306.

https://www.jstor.org/stable/24852276

https://doi.org/10.3354/meps122277

Rojas, N. G., Avelizapa, T., Roldán-Carrillo, H., Zegarra-Martínez, A. M., Muñoz-Colunga, L. C., \& Fernández-Linares (2007). A Field Trial for an EX-Situ Bioremediation of a Drilling Mud-Polluted Site. Chemosphere, 66, 1595-1600.

https://doi.org/10.1016/j.chemosphere.2006.08.011

Saner, S., Khattab, H., \& Perincek, D. (2005). Surface Expressions of the Ghawar Structure, Saudi Arabia. Marine and Petroleum Geology, 22, 657-670. https://doi.org/10.1016/j.marpetgeo.2004.12.006

Turekian, K. K., \& Wedepohl, K. H. (1961). Distribution of the Elements in Some Major Units of the Earth's Crust. Geological Society of America Bulletin, 72, 175-192. https://doi.org/10.1130/0016-7606(1961)72[175:DOTEIS]2.0.CO;2

UNEP (1985). Reference Methods for Marine Pollution Studies (pp. 31-39). United Nations Environment Program Regional Seas. 